\title{
USING AHP FOR THE EVALUATION OF THE DEVELOPMENT OF CAREER EDUCATION IN LATVIA
}

\author{
Veronika Bikse* \\ University of Liepāja \\ Liepaja, LV-3401, Latvia \\ E-mail: vbikse@lu.lv \\ Una Libkovska \\ Ventspils University College \\ Ventspils, LV-3601, Latvia \\ E-mail: Una.libkovska@inbox.lv \\ Peteris Rivza, Baiba Rivza \\ Latvia University of Agriculture \\ Jelgava, LV-3001, Latvia \\ E-mail: Peteris.Rivza@1lu.lv
}

\begin{abstract}
The purpose of this study is to explore and substantiate the possibilities of improving students' professional interests in career education in Latvia. Quantitative and qualitative research methods were used in the research. The survey was carried out as the key method to study students' professional interests. The Analytic Hierarchy Process (AHP) and the PEST method were used to analyze the possible development scenarios of career education in Latvia. The results indicate that the formation of professional interests in career education according to modern requirements is explained on the basis of the performed analysis of the possible development scenarios of career education; the development model of career education promoting the formation of professional interests has been worked out.
\end{abstract}

Keywords: Analytic Hierarchy Process (AHP), Career Education, Entrepreneurial Competence, Professional Interests.

\section{Introduction}

Nowadays the development of economy, the national competitiveness, as never before, depends on the developed human capital, people's professionalism, interest to work actively and being innovative. Only work, corresponding to a person's abilities, desires and interests, can ensure real creativity and successful work in a definite field. (Career Guidance, 2005) It means that the choice of a profession has always been and will be a topical issue.

The importance of this issue has increased nowadays because, firstly, different kinds of work set different demands to people. One profession demands high of movements, speed of reaction, perspicacity, dexterity, another - the ability to communicate with people, to work in a team, to manage the work of others or to obey the orders, etc. Besides, not every person, depending on the state of his/her health, physical and mental development, character or other personality features, can be equally suitable for any profession. Secondly, in the past people chose a profession, acquired the corresponding qualification and could work in the profession till the end of the working life. Nowadays it is necessary to develop and diversify one's qualification all through the life. It is important to maintain the acquired knowledge and skills to such a level that they are useful in the global labor market which is constantly changing. Today there are significant changes in technologies

\footnotetext{
* Corresponding author
} 
that result in new professions and new work places. (Hall, Mirvis, 1995) In order to use new technologies regularly, it is necessary to acquire new knowledge and skills so the initially chosen profession can be changed several times later in life. Thirdly, nowadays the attitude towards a person, his/her development, value orientation changes significantly and a competent person is put forward as the most important precondition of the development of knowledge-based, creative economy and competitiveness. Abilities are identified with a person's competence because along with satisfying the material and professional spheres it is also important to satisfy people's diverse needs. It means that the formation of professional interests should take place simultaneously with the child's development as a personality, the development of his/her key competences, including the development of the entrepreneurial competence. (CEC, 2005).

In Latvia the most essential problem of developing production in comparison with other EU countries is a relatively low effectiveness of application of knowledge, innovations and human resources. Young people's professional interests often do not correspond to the demands of the labor market resulting in a rather big number of drop-outs in the vocational and higher education institutions. In addition, trained specialists do not correspond to the demands of the labor market.

The formation of students' professional interests takes place in career education. The accessibility of qualitative career education is determined by the support of career education, including the professional training of career education specialists and the accessible resources. In Latvia "the situation in career education is insufficient". Ordinary teachers do not have the needed professional support to deliver career lessons; the class teachers often do not have the methodological basis to perform career education activities in their lessons. (Lemešonoka, 2012) Therefore the implementation of career education in general education secondary schools has not yet become a unity of activities that are integrated in the whole teaching/learning process. Hierarchy analysis method is used in the paper for the evaluation of the career education scenarios, for the analysis and interpretation of the obtained data.

\section{Career education in Latvia}

Career is a person's purposeful action to improve and express his/her competences all through the life and the stage of general secondary school is the beginning for its conscious formation which will continue in the higher education institution and all through the life. (Career development of work, 2008) Career education is a way how to help students to form their professional interests, understanding and skills that are necessary to make conscious decisions, to plan and form purposefully the growth of one's career. (Preparing youth for 21st century, 1999)

In education sector career education is a planned event where courses and programs in educational institutions are aimed at helping students to acquire and develop skills for proportioning their interests, abilities and possibilities, for setting the aims of one's career and managing one's career and providing knowledge and understanding about the employment world, its links with education, career planning and developing all through the life. (Eraut, Alderton, Cole, Senker, 2001) It means that career education plays an important role in the formation of professional interests; it is important to observe the theoretical ideas and objective conditions in its process in order to promote a correct choice of profession and further education according to the demands of the labor market and requirements of society. The content of a person's professional action and the formation of professional interests similar to the content of any social phenomenon are determined by several conditions: firstly, possibilities of students' development in different age groups; secondly, a complex approach to the development of key competences, including entrepreneurial competence; thirdly, demands of the labor market. (Bikse, 2011)

Professional interests are formed in all cycles of human life. (Spencer, Harris-Browsbey, 2002) Special attention is paid to the formation of professional interests in the childhood and younger years when children are getting ready for choosing the profession. The analysis of theories on professional 
interests and career development proves that the factors influencing the choice of the profession in the childhood are inquisitiveness, interests, researching and authorities (Hotchkiss, Borrow, 1996). (Gilligan, 1999) The exploration of interests in the childhood promotes the formation of professional interests in later life cycles. The kinds of the personality's professional self-realization are determined by the dominance of some external or internal factor in the youth therefore special attention in this process is paid to the formation of professional interests that promote the choice of the career. (Whity, Power, Halpin, 1997) Nowadays the support for the career development includes activities that are divided into three groups:

- Career information (preparing and providing);

- Career education (services, courses, programs);

- Career consultations (help in career planning, work trials, acquisition of job seeking and staying in the job skills).

Analyzing the experience of the European Union countries (Latvia, Lithuania, Estonia, Ireland, Germany, Finland, Denmark) in developing the career education it is possible to conclude that the provision of career education in the educational institutions is the responsibility of the Ministry of Education and Science and the education boards or other institutions coordinate it. The approach of career education development differs in each EU country. The responsibility to support this development on the policy level is shared by the Ministries of Education, Social and Employment Affairs in close cooperation with the Ministry of Economics which provides information on the development trends of the branches of national economy and the labor market in the country.

Career education programs in the educational institutions of the EU countries are implemented on the basis of three models: 1) schools have career centers ensuring career education and students' individual career consultations in the school; 2) career education as a lesson; 3) the issues of career education are integrated in everyday teaching/learning process.

The issues of career education in Latvia should be integrated in different stages of education. It determines the necessity to attract qualified staff in the implementation of career education. Thus, in the primary school teachers need the skill to provide information on professions and opportunities of choosing a profession as well as to be able to determine students' abilities and promote the development of their talent. As regards the secondary education, teachers need to motivate their students for a conscious choice of the career; teachers have to cooperate with employers to make a link between the career promotion opportunities and the education programs to be studied, to connect the theoretical and practical part of the teaching/learning process (Joma, Vasiļevskis, 2009).

In Latvia the Ministry of Education and Science is responsible for developing and introducing state education policy as well as for coordination the implementation of career education in the whole sector of education. State Education Development agency being under the Ministry of Education and Science provides information about education possibilities in Latvia and Europe and it also coordinates the cooperation of institutions involved in introducing the support system of career education. From February 2006 till August 2008 the EU project Provision of career education programs in the education system (KIPNIS) was implemented. (EU project, 2006) The project results were:

1) Implemented professional development of teachers working at schools (a 72 hours further education program for improving pedagogues' competences in career education);

2) Developed methodological, informative materials, including e-materials. Established the national database of education possibilities www.niid.lv, which provides information about the education opportunities for children and youth, for further education and higher education, self-assessment tests, services of the e-consultant and other topical information concerning education;

3) Developed professional higher education Master's study program "Career Consultant" which is aligned with the adopted profession standard of the career consultant.

Summarizing the information, it should be noted that the project KIPNIS has laid foundation for the purposeful implementation of career education in general secondary educational institutions. However, the support of career development in the education system is not highly ensured for 
everyone who needs it. The implementation of career education in general secondary schools has not yet become a unity of activities that are integrated in the whole teaching/learning process.

The study of the students' professional interests shows that the $94 \%$ of the surveyed students (altogether 633 young people from general secondary schools of Latvia, aged 18-19, participated in the study) indicated the necessity of help in choosing the profession. Students lack information about professions, their content, and the development trends of the labor market. $62 \%$ of the surveyed students admit that the help provided by school in choosing the profession is insufficient. More than a half $(53 \%)$ of survey participants ask help from their friends and classmates in order to choose their profession, they rely less on the help of professional consultants. 55\% of students note that in choosing the profession they have to develop such competences as: communication in the foreign language and state language, while only $1 \%$ of the respondents indicate that initiative and enterprising are important in choosing the profession. The choice of the educational institution is influenced by its location, an opportunity to study in the state-financed programs, lower tuition fee (52\%), the popularity of an educational institution and teachers' recommendations about the opportunities of further education influence $33 \%$ of the respondents, the possibility to study in the evenings or parttime as well as the available infrastructure is important for $15 \%$ of respondents.

The analysis of the obtained research data allows concluding that students are often unable to combine their interests, desires, abilities and knowledge with the existing situation in the labor market. Students rely on the opinions of their friends and classmates when choosing their profession. Students have insufficient information about further education in the acquisition of the profession.

Summarizing the information above, the authors conclude that students' professional interests are not formed on the basis of their abilities or talents, the demands of the labor market. In addition, students' professional interests are not formed in the unity with the development of the entrepreneurial competence. This proves that the career education events which are held in general secondary schools are insufficient which justifies the necessity to improve the management of career education.

\section{Hierarchy analysis of the development scenarios of career education}

\section{1. Research Methodology and Participants}

Career education is a dynamic and complex system. Equally complicated methods should be used for its research. Due to a complex character of the career education the interdisciplinary approach should be used which, in turn, means including both the qualitative and quantitative indicators in the analysis. Thus experts' survey and the analysis of opinions were used to evaluate the effectiveness of development alternatives of career education.

In order to organize the experts' work scientifically correctly and to process the results of experts' assessment the authors used the Analytic Hierarchy Process (AHP) and the key principles of the experts' method. (Saaty, 1990, 2008) The experts' survey and the algorithm of the AHP which were adjusted to the research methodology, i.e., the assessment of the alternative versions of improving the career education (the possible scenarios) were used in the research.

If the two methods are combined, the following is achieved: qualitative analysis of the researched object; qualitative factors that can be measured and which significantly influence the development of the object; variants of the prognosis that can be ranged; grouping, ranging of different factors, indicators and defining the priorities; preparing the decisions.

The offered approach in its initial stage allows structuring the career education and assessing the importance of its structural elements, whether the influence of different factors on career education is complex, mediated and connected with different external factors. The combination of determinants states the conditions in which the career education can develop successfully. The hierarchy of the career education system was formed using the AHP as well as taking into account the information obtained by monographic analysis about the development of career education in Latvia and Europe. 
The following stages were included in performing the assessment of career education according to AHP method (Saaty,2008):

1) defining the aims, directions and objectives;

2) designing the qualitative model of the phenomenon in a hierarchy that includes the alternative versions and criteria for achieving the aim reflecting the peculiarities of career education in Latvia;

3) working out the assessment matrix on the basis of ratios concerning the significance of aims;

4) filling in the matrices with experts' assessment using the method of pair comparison;

5) synthesis of the priority alternatives using the linear composition of priorities of hierarchy elements, the mathematical summary of the assessments;

6) testing the coherence of judgments by calculating the coherence index (CI) and coherence relations (CR);

7) evaluation: determines more factors that influences the choice of the model, evaluation of the definite criteria, evaluation of the groups of criteria - it optimizes the method, adjusts it to monitoring performance;

8) interpretation of results, choice of the models;

9) justification of the assessment criteria taking into consideration the development possibilities.

AHP method is a procedure that combines the economic, social and political environment in aims and assessment criteria. (Rivža P., Rivža B., 2007) Such an approach to the decision making would improve the control on observing the interests of different target groups of the society in the decision making process.

\subsection{Experts' interviews, SWOT method}

Scenarios of career education were assessed by 7 experts: a head of the regional branch of the higher education institution, a director of the vocational school; a director of the primary school; a head of the regional branch of the State Employment Agency; a career consultant of the State Employment Agency; a head of the regional municipality; a director of the enterprise.

Experts were selected on the basis of evaluating the competence level performed earlier. Experts whose field of action, experience, and position are sufficiently significant were selected for the survey, to assess the offered priorities in the development of career education. The coherence relations were defined to validate the precision of the experts' assessment which shows how coordinated the experts were when making the table.

The standardization of the obtained data was performed at the initial stage of data processing when calculating the priority vector coordinates for each criterion.

Interviews with experts about the possible development of career education and the assessment of the possible development scenarios were conducted in the framework. The involved experts were also surveyed. The survey method was a partly structured interview conducted face-to-face. The interviews took place from December 2010 till January 2011. The aim of the interview was: 1) to find out the possibilities of developing the career education and the possible development scenarios; 2) to find out the necessary improvements for career education programs in future. The analysis of the results of experts' assessment results was performed according to the main themes: opportunities and obstacles to the development of career education in Latvia; experience in the support activities of career development; support to career education programs and models of their implementation.

Carrying out of the experts' method (the procedure of obtaining the experts' assessment) and the evaluation of the results with the help of the approbated mathematical methods were used in the assessment of the possible development scenarios of career education. In order to evaluate the strengths and weaknesses of career education the authors performed the SWOT analysis using the data of the Ministry of Education and Science, Ministry of Welfare and the support programs of career education of the State Employment Agency (SEA). (Table 1) 
Table 1. SWOT analysis of career education.

\begin{tabular}{|c|c|}
\hline Strengths & Weaknesses \\
\hline $\begin{array}{l}\text { Legislation that corresponds to the European } \\
\text { key guidelines and that regulates the } \\
\text { development of services of career } \\
\text { education has been worked out in Latvia; } \\
\text { Legislation determines the rights of young } \\
\text { people to receive career services that } \\
\text { correspond to his/her individual needs; } \\
\text { There are definite demands for the providers } \\
\text { of career education to guarantee } \\
\text { qualitative services; } \\
\text { There is a possibility to acquire career } \\
\text { education at one's living place, in general } \\
\text { secondary school; } \\
\text { Career education is managed by qualified } \\
\text { specialists; } \\
\text { There are study programs in higher education } \\
\text { institutions. }\end{array}$ & $\begin{array}{l}\text { The youth have insufficient access to } \\
\text { information on the possibilities of career } \\
\text { education in regions; } \\
\text { Training of specialists on career education in } \\
\text { higher education institutions is not } \\
\text { sufficient; } \\
\text { Low financial state support to the } \\
\text { implementation of career education in } \\
\text { Latvia; } \\
\text { Poor remuneration of the staff in career } \\
\text { education; } \\
\text { There is a lack of conformity between the } \\
\text { formation of professional interests and } \\
\text { the demands of the labor market; } \\
\text { There is insufficient cooperation between the } \\
\text { vocational education institutions and } \\
\text { employers in ensuring the practice for the } \\
\text { youth. }\end{array}$ \\
\hline Oppc & Threats \\
\hline $\begin{array}{l}\text { To develop career education programs in the } \\
\text { general secondary school for students of } \\
\text { all age groups; } \\
\text { State financial support for career education; } \\
\text { Attraction of qualified staff; } \\
\text { The possibility to attract co-financing from } \\
\text { international funds for the } \\
\text { implementation and development of } \\
\text { career education. }\end{array}$ & $\begin{array}{l}\text { The attitude of the employers is still quite } \\
\text { negative towards the involvement of } \\
\text { young people who have no professional } \\
\text { work qualification; } \\
\text { The possibility that highly qualified } \\
\text { specialists move to other countries; } \\
\text { The possible increase of young specialists } \\
\text { graduating abroad and staying to work in } \\
\text { those countries; } \\
\text { The economic instability of the country and } \\
\text { the world threatens the implementation } \\
\text { of the worked-out programs of career } \\
\text { education. }\end{array}$ \\
\hline
\end{tabular}

The performed SWOT analysis allows concluding that the development of career education has many advantages and strengths creating positive conditions for the formation of the youths' professional interests, for choosing the profession and study program according to the young people's abilities, skills, interests and demands of the labor market.

The main shortcomings in the development in the career education are the insufficient state financing for the implementation of career education programs in general secondary schools, poor remuneration of the staff which could also serve as one of the reasons why the quality of career education could decrease.

One of the opportunities for promoting career education is the possibility to attract the financing from EU structural funds in order to develop the services of career education in general secondary schools effectively and qualitatively, to promote the modernization of the material and technical basis. However, a strong threat for the development of the services of career education is the involvement of the youth in the labor market, the promotion of the youths' employment. The broadening of international cooperation increases the possibilities of the competition and the possibility that highly qualified specialists might move to foreign countries.

\subsection{Development scenarios of career education}


The analysis of theories, international and Latvian experience of career education offers three possible development scenarios in schools.

1st scenario: “The current model - career education is implemented in class teacher's lessons". The class teacher plans and organizes the implementation of career education in the general secondary school.

2nd scenario: “Career consultations in career centers". Students visiting the career center get information about professions, educational institutions, possibilities in the labor market. Consultation of students in the issues of choosing education and profession is voluntary with the aim to promote students' ability to make a decision in choosing the profession.

3rd scenario: “Career education as a lesson in general secondary school”. Students' career education takes place in general secondary schools at the career education lessons in accordance with the students' age. Differentiated approach was used for working out and assessing the scenarios: scenarios were worked out by the authors but they were assessed by experts. The criteria hierarchy for determining the priorities was developed during the research. Four levels were worked out (Figure 1).

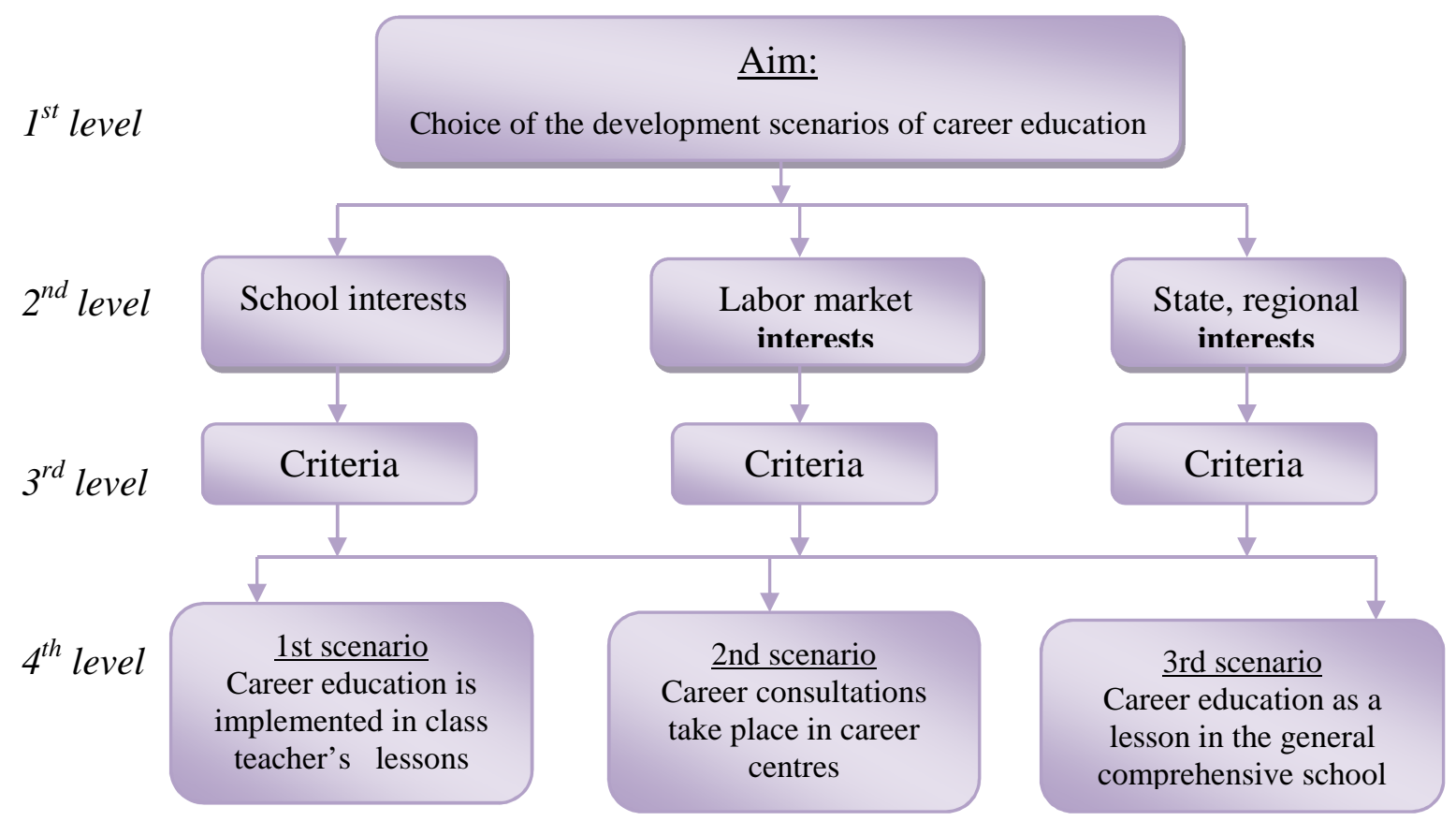

Figure 1. Criteria's hierarchy in career education.

The aim of the first level is choosing the development scenarios of career education. On the second level the interests of all the involved groups are offered: school interests, labor market interests, state and regional interests. On the third level criteria for achieving the aim are placed - indicators of career education that are divided according to interest groups. On the fourth level the possible versions of the development of career education are positioned.

The next stage of the method envisaged identifying and defining the assessment criteria. Taking into consideration the previously performed socially economic system analysis of career education the following assessment criteria were defined. The division of the interests of all the involved groups in criteria on the third level of hierarchy was worked out:

1) Interests of general secondary schools: accessibility of the school (distance), number of students, financial stability, quality of the teaching/learning process, number and accessibility of qualified staff, the result-oriented teaching/learning process.

2) Labor market interests: development of professional interests, development of entrepreneurial skills, the readiness of the graduates to join the labor market, accessibility of 
qualitative workforce, productivity, innovative entrepreneurship.

3) Regional and state interests: rational division of students in the study fields, employability of the graduates according to the study fields, development of regional higher education institutions (placement of the financial resources), polycentric development of the state, competitiveness of the state, creation of innovative products.

The division of the interests of all the involved groups in criteria on the third level of hierarchy is presented in Table 2 .

Table 2. Division of interests of groups involved in career education on the third level of hierarchy.

\begin{tabular}{|c|c|c|}
\hline $\begin{array}{l}\text { Interests of general } \\
\text { secondary schools }\end{array}$ & Labor market interests & Regional, state interests \\
\hline $\begin{array}{l}\text { - accessibility of the } \\
\text { school (distance), } \\
\text { - number of students, } \\
\text { - financial stability, } \\
\text { - quality of the } \\
\text { teaching/learning process, } \\
\text { - number and accessibility } \\
\text { of qualified staff, } \\
\text { - result-oriented } \\
\text { teaching/learning process. }\end{array}$ & $\begin{array}{l}\text { - development of } \\
\text { professional interests, } \\
\text { - development of } \\
\text { entrepreneurial skills, } \\
\text { - the readiness of the } \\
\text { graduates to join the labor } \\
\text { market, } \\
\text { - accessibility of qualitative } \\
\text { workforce, } \\
\text { - productivity, } \\
\text { - innovative } \\
\text { entrepreneurship. }\end{array}$ & $\begin{array}{l}\text { - rational division of students } \\
\text { in the study fields, } \\
\text { - employability of the } \\
\text { graduates according to the } \\
\text { study fields, } \\
\text { - development of regional } \\
\text { higher education institutions } \\
\text { (placement of the financial } \\
\text { resources), } \\
\text { - polycentric development of } \\
\text { the state, } \\
\text { - competitiveness of the state, } \\
\text { - creation of innovative } \\
\text { products. }\end{array}$ \\
\hline 6 criteria & 6 criteria & 6 criteria \\
\hline
\end{tabular}

The next stage envisaged performing the expertise (procedure of obtaining experts' assessments) to find out the importance of ratios for each factor. After the survey all the data were processed. When all the project hierarchies had been correctly formed, calculations were done. The result of calculation shows which of the alternatives was the most acceptable in the aspect of all the mentioned criteria. The results of experts' survey were further analyzed taking into account the context of career education. The $3^{\text {rd }}$ scenario "Career education as a lesson in general secondary school" received the highest average assessment in the summarizing assessment in all groups of criteria - 0.34, thus, according to experts' assessment it was considered the most advisable development scenario of the career education system in Latvia; however, there was rather considerable dispersion of experts' assessments, namely, the smallest value of the scenario was 0.13 , and the greatest 0.57 , which shows that experts disagreed. The next advisable scenario was the $1^{\text {st }}$ one "The current model - career education is implemented in class teacher's lessons"- 0.24, and the $2^{\text {nd }}$ scenario "Career consultations in career centres" received the lowest assessment -0.23 . The analysis of the defined scenarios in the groups of criteria showed that the $3^{\text {rd }}$ scenario "Career education as a lesson in general secondary school" received the highest average assessment -0.15 , the $1^{\text {st }}$ and $2^{\text {nd }}$ scenarios, in their turn, were assessed 0.08 and 0.06 , respectively. (Figure 2)

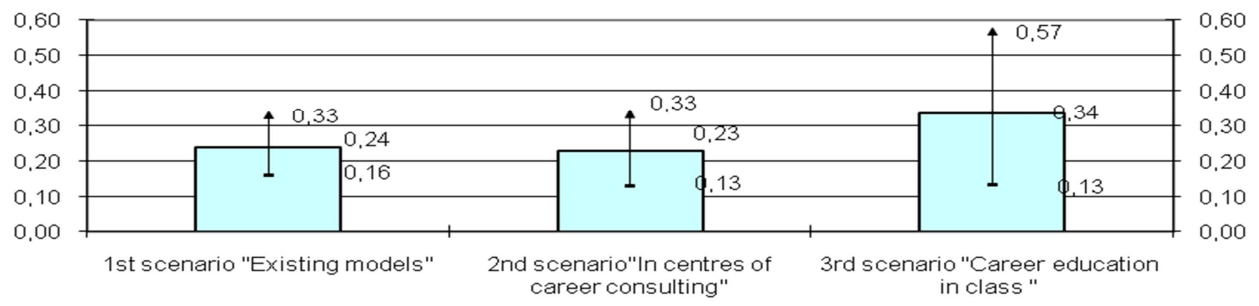

Figure 2. The summarized assessment of the experts on the development scenarios of the career education system. 
Taking into consideration the assessment provided by the experts of career education, it is possible to conclude that it is necessary to develop career education in general secondary schools ensuring the respective funding and development possibilities in the way that career education activities are implemented according to the aims and they promote the youth's choice of the profession and studies on the basis of students' abilities, talents, interests and the demands of the labor market.

\section{CONCLUSIONS}

The analysis of the development possibilities of career education and the performed hierarchy analysis permits to conclude that: firstly, schools lack a standardized system of forming professional interests in implementing career education. The understanding about the career education, the attitude towards it, planning and implementation of the career education in schools are very different. The implementation of career education often depends on how informed and interested the school administration is as well as it depends on teachers' competence, i.e., whether subject teachers are able to explain the issues of career education. Secondly, schools lack understanding and informational and methodological materials in career education for working with students. Thirdly, there is a lack of qualified specialists to form professional interests in the implementation of career education in secondary schools.

Taking into consideration the experts' assessment, an advisable development model of forming professional interests promoting career education would be Career education as a lesson in general secondary school. Career education is implemented:

1) during career lessons (run by the teacher of career education, career consultant; themes are developed according to students' age groups);

2) in the framework of the unified school program on career education - in the events organized by the school (e.g., project weeks, shadow days, thematic lectures, excursions, meetings with the employers, etc.);

3) integrating in school subjects according to the unified school program on career education (implemented by career education teachers in cooperation with subject teachers according to students' age groups);

4) combining the career education program and interest education;

5) using the cooperation model between the career education teacher (career consultant) and the school staff (administration, class teachers, subject teachers, librarian, medical staff, social pedagogue, psychologist);

6) in cooperation with parents. By integrating the management model of career education that promotes the formation of professional interests, the career education events would be implemented according to the aims and would promote the youth's choice of the profession and further studies on the basis of students' abilities, talents, interests and the demands of the labor market.

\section{ACKNOWLEDGEMENTS}

Publication and dissemination of research results has been made due to the funding of the ERAF Project „Promotion of scientific activities of LLU”, No 2010/0198/2DP/2.1.1.2.0/10/APIA/VIAA/020

\section{REFERENCES}

Bikse, V. (2011). Entrepreneurial Abilities. Rīga: Art \& Design SIA.

Career Guidance: A Handbook for Policy Makers. (2005). OECD. 
Career development of work (2008). A review of career guidance to support people in employment. European centre for the Development of Vocational Training.

Eraut, M., Alderton, J., Cole, G., Senker, P. (2001). Development of Knowledge and Skills at Work. In Coffield F. (ed), Differing Visions of a Learning Society, 1, 231-262. Policy Press: Bristol.

EU project Provision of career education programs in the education system. 2006. (http://www.viaa.gov.lv/lat/karjeras atbalsts/ informativie_izdevumi) (Accessed on March 15. 2012.)

Joma, A., Vasilevskis, G. (2009). Career education in school. Riga: VIAA.

Gilligan, R. (1999). Enhancing the resilience of children and young people in public care by mentoring their talents and interests. Child and Family Social Work,4, 187-196.

Hall, D.T., Mirvis, P.H. (1995). The new career contract developing the whole person at midlife and beyond. Journal of Vocational Behavior,35, 64-75.

Lemešonoka, I. (2012). The problems of career education in comprehensive schools. (http://www.diena.lv/skolas) (Accessed on May 25. 2012.)

Preparing youth for 21st century: the transition from education to the labour market (1999). Proceeding of the Washington D.C. conference 23-24 February. Paris: OECD.

Recommendation of the European Parliament and of the Council on Key Competences for Lifelong Learning (2005). Commission of the European Communities (CEC). Brussels: Commission of the European Communities.

Rivža, P., Rivža, B. (2007). Experience in the use of the Analytic Hierarchy Process in Latvia. ISAHP2007 Proceedings of the $9^{\text {th }}$ International Symposium on the Analytic Hierarchy Process for Multi-criteria Decision Making, August 2-6, 2007, Viña del Mar, Chile, (http://www.isahp.org/2007Proceedings/Papers/Working\%20Sessions/Project\%20Evaluation/AHP\%2 0\%20in\%20Latvia.pdf ) (Accessed on February 15. 2013.)

Saaty, T.L. (1990). How to make a decision: The Analytic Hierarchy Process. European Journal of Operatonal Research, 9-26.

Saaty, T.L. (2008). Making Decisions in Hierarchic and Network Systems. Int. J. Applied Decision Sciences, 1, 24-79.

Saaty, T.L. (2008). Decision Making For Leaders. The Analytic Hierarchy Process for Decisions in a Complex World, 24-79.

Spencer, R.D., Harris-Browsbey J. (2002). Career Development Interventions in the $21^{\text {st }}$ Century. New Jersey: Merrill Prentice Hall.

Whity, G., Power, S., Halpin, D. (1997). Devolution and choice in education: the school, the state, the market. Buckingham, Philadelphia: Open University Press. 